\title{
ASSOCIATIONS BETWEEN ENTREPRENEURIAL EMPOWERMENT AND REASONS FOR SELF-EMPLOYMENT
}

\author{
B Urban
}

Department of Entrepreneurship, University of Johannesburg

\begin{abstract}
Building on previous research relating to entrepreneurship, empowerment and self-employment, this article investigates the relationship between entrepreneurial empowerment, entrepreneurial self-efficacy and self-employment. These constructs are formulated into distinct factors and a sample of undergraduate students $(N=112)$ early in their careers surveyed to establish the structure formed by these factors. These instruments are tested and shown to provide robust scales able to ensure construct validity and reliability. Multiple correlational and multiple regression analysis are then conducted to test the relationships between the specified variables, with results indicating almost unequivocal support for the hypothesised associations between entrepreneurial empowerment and reasons for business start-up. In particular the "risk-taking" factor is found to have great predictive power on various reasons provided for business start-up. Several practical and theoretical implications are drawn from the empirical results and integrated with established conceptual findings.
\end{abstract}

JEL D8, J24, L26, M13

\section{1}

\section{Introduction}

\subsection{Background to the study}

Modern businesses are often characterised as turbulent and dynamic. Individuals who work in them, under these conditions, need to be entrepreneurial. However, instead of becoming adaptable, flexible, autonomous and entrepreneurial, many individuals in this rapidly changing, complex environment tend to react in the opposite way. Whetten and Cameron suggest empowerment is the key to developing the characteristics required for such a changing environment, saying that 'to empower means to enable and to develop a sense of self-efficacy' (2005: 403). Empowered individuals feel less constrained and more selfefficacious, autonomous and creative, and are more likely to be innovative and expect more success (Conger \& Kanungo, 1988; Thomas \& Velthouse, 1990).
When people are empowered they feel efficacious in that they possess the capability and competence to perform a task successfully. They feel a sense of personal mastery and confidence. Some researchers (such as Bandura, 1997) believe that self-efficacy is the most important element in empowerment, since it determines whether people will try and persist in attempting to accomplish a difficult task. Kantor (2002) argues that empowerment and innovative behaviour are inextricably linked.

Empowerment in the field of entrepreneurship is most commonly featured in literature on minority and disadvantaged groups (Kantor, 2002), where the focus is on the individual's ability to control his/her own destiny. This kind of ability is often referred to as self-enabled empowerment.

Empowerment can be a legitimate aim of educational interventions. Such interventions attempt to link skills development, foresight and knowledge about innovation and enterprise with empowerment of young individuals, to 
help them create a new venture (O'Conner \& Ramos, 2006). The success of entrepreneurs is highly dependent on personal motivation and will to succeed, which is analogous to feeling empowered.

The focus of this article is on the individual's perception of empowerment in the context of starting a business. This investigation is relevant in South Africa (SA), where not only is empowerment widely advocated, but also where there is a need to empower individuals to develop their potential to be entrepreneurs (especially for sectors of the population such as women and previously disadvantaged groups who arguably lack entrepreneurial traditions) by increasing perceptions of self-efficacy.

Starting a business or initiating a new venture is often described as a purposive and intentional career choice, of which entrepreneurial selfefficacy (ESE) is a key antecedent (Chen, Greene \& Crick, 1998). Perceived self-efficacy is the strongest single predictor of career choice (Bandura, 1986) and self-reported competence predicts entrepreneurial performance (Chandler \& Jansen, 1992). Since self-efficacy reliably predicts the scope of career options considered, occupational interests, perseverance in difficult fields, and personal effectiveness, it has been related to the pursuit of entrepreneurial activity (Markman, Balkin \& Baron, 2002).

Since starting a business and entering into self-employment is often the first step of an entrepreneurial career (Katz, 1990), it is important to identify motives and reasons for starting the business. The extant literature suggests a plethora of reasons for start-ups, which include: the need for personal development or independence, approval seeking, following the example of others, desire for financial success and the search for self-realisation (Shane, Kolvereid \& Westhead, 1991; Douglas \& Shepherd, 2002; Drnovsek \& Glas, 2002).

This study thus begins with a literature review, so as to build on previous research relating to entrepreneurship, empowerment and selfemployment. This review aims to survey the key concepts behind the central research focus, which investigates the relationship between entrepreneurial empowerment (EE), explored using a model of entrepreneurial self-efficacy
(ESE), and identifies reasons for business startups and self-employment. The methodology primarily uses correlation as a means of analysis, to predict to what extent individuals who perceive themselves as empowered are more inclined towards self-employment as a career option.

\subsection{Previous research on empowerment}

Empowerment is not a new construct and has been defined in a variety of ways, predominantly in organisational research, as:

- the motivational concept of self-efficacy (Conger \& Kanungo, 1988);

- a philosophy of delegating (Shackleton cited in Cloete, Crous \& Schepers, 2002);

- an essential information-sharing process that empowers individuals and affects job performance; and

- a participative decision-making process (Cloete, Crous \& Schepers, 2002).

Empowerment can be grouped into structural, leadership and motivational approaches, and described as a cognitive state, characterised by perceived control, competence and goal internalisation (Menon, 2001). Typically, empowerment is conceptualised as a multifaceted construct (Thomas \& Velthouse, 1990). Spreitzer (1995) says that empowerment is manifested in a set of four cognitions reflecting an individual's work-orientation role, namely meaning, competence (synonymous with self-efficacy), self-determination and impact. Similarly, according to Appelbaum and Honeggar (1998), competence is the felt accomplishment of skilful task performance. For Thomas and Velthouse (1990), competence is the degree to which a task is successfully performed, and is analogous to self-efficacy.

General assumptions about definitions of empowerment are made explicit by Spreitzer (1995). Firstly, empowerment is not an enduring personality trait generalisable across situations, but a set of cognitions shaped by the work environment. Secondly, empowerment is a continuous variable, which implies that individuals must be viewed as more or less empowered, rather than empowered or not. 
Lastly, empowerment is not a global construct generalisable across different life situations and roles but specific to the work domain.

Although awareness of empowerment issues has increased greatly in the workplace, chief executive officers (CEOs) tend to work against empowerment both consciously and unconsciously (Drnovsek \& Glas, 2002). Although there is much talk about empowerment as a way for bettering the personal lives of individuals, it has become a misused construct, which according to Bandura (1997: 477)

is heavily infused with promotional hype, naive grandiosity, and virtually every brand of political rhetoric. Empowerment is not something bestowed through edict; it is gained through development of personal efficacy that enables people to take advantage of opportunities and to remove environmental constraints.

Such sentiments are particularly relevant in SA, where empowerment is not only widely advocated but also legislated for in terms of Black Economic Empowerment (BEE), a strategy designed by the government to introduce black, coloured and Asian citizens into the business landscape without disrupting the economy (SA Business Guidebook, 2005/6).

The legacy of apartheid education, which this BEE strategy acknowledges, includes damage done to the self-esteem, motivation and creativity of previously disadvantaged individuals. Building entrepreneurial capacity at schools requires inculcating a 'can-do' attitude in learners and helping them develop the selfbelief and skills needed for entrepreneurial aspiration (Driver, Wood, Segal \& Herrington, 2001). Empowerment embraces the idea that individuals should be enabled to maximise the opportunities available to them despite the presence of constraints (Van Jaarsveld, 2005).

Considering the role of the individual in venture creation, understanding entrepreneurship must begin with a conceptual framework of human agency. Bandura (2001) proposes that to be an agent is to intentionally make things happen by one's own actions. The entire entrepreneurial process unfolds because an individual acts and is motivated to pursue opportunities. Effecting agency is thus an integral aspect of empowerment; it blazes a trail toward activities encompassing innovation and entrepreneurship. A key element in the process of empowerment is the innovator's perception of innovation as possible. If an individual is cognitively empowered but lacks the requisite skills, knowledge and attitudes, his/her empowerment is nullified. Therefore O'Conner and Ramos (2006) suggest building cognition through foresight processes in conjunction with innovation and enterprise skills and attitudes.

In conclusion, the multifaceted construct of empowerment can be viewed as an outcome of agency, the ability to act, of which belief in one's own efficacy is one of the most important foundations (Bandura, 1997: 477).

\subsection{Belief in self-efficacy related to empowerment}

Belief in one's self-efficacy influences what challenges one undertakes and how long one perseveres in the face of obstacles. Selfefficacy is an important motivational construct that influences an individual's choices, goals, emotional reactions, efforts and persistence. It refers to the individual's convictions about his/her abilities, or belief in his/her capacity to perform (Bandura, 1986, 1997, 2001).

Self-efficacy is an important construct in behavioural management and has been defined as 'people's judgments of their capabilities to organize and execute courses of action required to attain designated types of performance' (Bandura, 1986: 391). Two decades of empirical research have generated a large number of studies demonstrating the positive relationship between self-efficacy and various motivational and behavioural outcomes in clinical, educational and organisational settings, which have been extensively documented (e.g. Krueger \& Brazeal, 1994; Chen, Greene \& Crick, 1998; Krueger, Reilly \& Carsrud, 2000; Drnovsek \& Glas, 2002; Bradley \& Roberts, 2004).

Previous results of the study of motivation in the context of entrepreneurship in terms of basic concepts such as achievement need, risk taking, tolerance of ambiguity and locus of control have yielded mixed results. However, results 
have been more consistent for constructs such as goal setting and self-efficacy. Self-efficacy particularly is identified as a key motivational component in Ford's 1996 model of individual creative action.

Belief in efficacy can raise and sustain motivation but cannot alone produce heightened performances if the necessary sub-skills are completely lacking. Of course most people do not hold unfounded beliefs of their own efficacy entirely unrelated to their capabilities. Nor does perceived self-efficacy involve only a one-way dependence on sub-skills. But proactive belief in one's efficacy and capability for self-development can lead to capacity being converted to capability.

Resilient self-efficacy enables people to override repeated rejection; this is important because early rejection is the rule rather than the exception in many creative endeavours and the more innovative the work the greater the risk of rejection. An optimistic sense of efficacy contributes to psychological well-being; this is demonstrated when the skills and beliefs of anxious and depressed people are compared with those of people who are unburdened by such problems. The groups differ little in their actual skills but they differ substantially in their beliefs about their efficacy.

Self-efficacy is also linked to initiating and persisting in behaviour under high uncertainty, to setting higher goals and to reducing threat rigidity and learned helplessness (Bandura, 1986), all of which resonate with desired entrepreneurial behaviour. To be blunt: no selfefficacy, no entrepreneurial behaviour (Krueger \& Brazeal, 1994).

Researchers, however, often ignore the concept of self-efficacy despite its importance and proven robustness at predicting both general and specific behaviour (Krueger et al., 2000: 418). Unlike personality traits, selfefficacy can be developed through training and modelling. Efficacy judgements are task-specific and regulate behaviour by determining task choices, effort and persistence. Self-efficacy also facilitates learning and task performance particularly early in the learning process (Stevens \& Gist, 1997). Self-efficacy can also change as result of learning, experience and feedback
(Gist \& Mitchell, 1992: 4), and persons who believe that their skill and ability set is adequate for achieving success with new ventures are motivated to exert the necessary effort.

These findings support the view that those who have a high sense of efficacy view situations as presenting realisable opportunities. This link to motivation for start-up ventures, as a critical feature of empowerment, will now be examined.

\subsection{Motives for starting a business}

Personal motives affect both start-up decisions and the start-up processes. Models and theories that delineate how motivations influence the entrepreneurial process are copious. For instance, a model used by Shane, Locke and Collins (2003) explains how the relative power of a particular motivator varies depending on which part of the entrepreneurial process is being investigated. Similarly, by extending existing motivational models to integrate the start-up decision with issues of strategy formulation and implementation, sustained entrepreneurial behaviour is delineated by Naffziger, Hornsby and Kuratko (1994: 33). Gatewood, Shaver, Powers and Gartner (2002) investigate the role that expectancy of entrepreneurial performance has on perceived ability in motivating persons to persevere in an entrepreneurial task. Their findings suggest that the feedback individuals receive regarding their entrepreneurial ability changes their expectancies regarding future business start-ups, but do not alter task effort or quality of performance. Other relevant motivational concepts linked to entrepreneurial behaviour and start-ups include the need for independence, drive and egoistic passion (Shane et al., 2003).

The goal of this study is to explain the factors that motivate an individual to select an entrepreneurial career (i.e. to have high entrepreneurial intentions). This requires indicating how the key concepts discussed so far interrelate. Due to the complexity of the entrepreneurial process, the focus of this study is one factor, self-efficacy, which clearly plays a significant role in empowerment and selfemployment intentions. 
The comprehensive literature review has indicated the current extent of knowledge on this topic, and enabled us to identify salient variables. The following hypotheses can now be formulated and set at the 0.01 significance level:

H1: Entrepreneurial empowerment along with intention towards self-employment is positively associated with reasons for start-up.

$\mathrm{H} 2$ : Entrepreneurial empowerment explains a significant proportion of variance in reasons for start-up.

\section{2}

\section{Research methodology}

\subsection{Study design}

In choosing a research methodology for this study, particular consideration was given to the location of the data, the gathering of the data, instrument design and treatment of the data (Cooper \& Emory, 1995). A quantitative approach was chosen, using a cross-sectional predictive study design. This design is suited to solving the main research question, and addressing the limitations of previous studies by empirically testing hypotheses about which speculation is rife.

The measures used in this study were drawn from previous studies and include items relating to:

- self-employment intent,

- entrepreneurial empowerment (using the ESE instrument),

- reasons for and against potential start-ups and

- demographic characteristics that previous research has identified as relevant to this type of inquiry.

First the measures were subjected to factor analysis to establish construct validity and reliability. The hypotheses were tested using several significance tests, including descriptive and inferential statistics and multiple correlation and regression analyses to determine the predicted relationships between the specified variables. Correlation calculates an index measure of the nature of the relationship between variables. Regression predicts the values of a dependent variable (Cooper \& Emory, 1995: 477).

As in other similar studies (e.g. Kolvereid, 1996), our study uses a sample of students (N $=112$ ) in their early careers. The students were asked to state whether they prefer running their own businesses or being employed by someone else. This measure of choice intention (Ajzen, 1991) was followed up a series of questions pertaining to reasons for and against start-up. This link is pertinent, since the reasons that individuals offer for starting a venture or not are traditionally considered to be the basis of intentions (Douglas \& Shepherd, 2002).

The study sample was purposive and composed of prospective entrepreneurs, namely secondand third-year undergraduate students studying entrepreneurship, small business management or commerce. These students have been exposed to entrepreneurship modules and several of them are also involved in 'students in free enterprise' (SIFE) projects, so they naturally have an inclination towards self-employment. Scherer, Adams, Carley and Wiebe (1989) suggest that student populations add control and homogeneity to such studies because individuals studying business already have an interest in pursuing business-related careers and students have the education required to run a business, i.e. they have the basis for evaluating their selfefficacy in some of the skills and abilities used in entrepreneurial careers.

Once the target population was defined, a sampling frame was constructed. The frame selection process for this study can be viewed as a trade-off between practical considerations on the one hand and the demands of randomisation and generalisability on the other (Mouton, 2002: 135). Because of practical considerations, the instrument was distributed to students in a classroom setting, which allowed the researcher to maintain control over the environment. This ensured that a high response rate was achieved.

\subsection{Instrument design}

Psychological empowerment is often measured with the Measuring Empowerment Questionnaire (MEQ). However, this instrument is typically 
used in an organisational or employee context and related to job satisfaction (Buitendach \& Hlalele, 2005). As discussed in section 1 , the focus of this study is on self-efficacy, which has been validated by previous studies (Bandura, 1997) but not adequately applied in entrepreneurship research. Self-efficacy reliably predicts the scope of career options considered, occupational interests, perseverance in difficult fields and personal effectiveness; it is not only related to the pursuit of entrepreneurship, but is also adequate for measuring entrepreneurial empowerment, if set in a suitable methodology as for this paper.

Based on various ESE conceptualisations (Noble, Jung \& Ehrlich, 1999; Chen et al., 1998; Anna, Chandler, Jansen \& Mero, 2000), several different items capturing the dimensions of EE were identified and included in the instrument as questions relating to opportunity recognition, innovation, management, risk taking and financial control. Respondents were asked to rate their current competence in each item (rated on a 1-5 Likert scale from very high to very low). Because of the relative newness of the EE construct, exploratory factor analysis was conducted based on the different subdimensions of the EE construct. The internal consistency of the instrument was tested and reliability statistics indicated relatively high internal consistency and homogeneity between the items; Cronbach Alpha scores of 0.810 and above were deemed acceptable, since the commonly used threshold value for acceptable reliability is 0.70 (Nunnally, 1978).

\subsection{Factor analysis}

Factor analysis, with principal axis factoring extraction using Barttlett's test of sphericity and the Kaiser-Meyer-Olkin measure of sampling adequacy, produced satisfactory results. Factor loadings greater or equal to 0.30 are generally regarded as significant, and factors with eigen values greater than 1 (based on scree tests and Kaiser's stopping rule) are used to decide the optimal number of factors to retain (Cooper \& Emory, 1995).

The alpha for each individual factor was calculated using only those variables chosen for their loading in the sorted rotated factor-loading matrix. For each factor, only those variables with a positive rotated factor loading on that factor and a zero loading on all other factors were selected. Table 1 provides the results of the final five factors with the different factor loadings and Table 2 summarises the factors' eigen values, percentages of variance explained and Cronbach's Alphas.

\subsection{Sample characteristics}

As in previous studies on individual differences in entrepreneurship, the following demographic control variables were measured, with the results indicated in brackets: age (33 per cent in the 17-20 category; 53 per cent in the 21-24 category), gender (male $=54$ per cent; female $=55$ per cent), level of education (controlled), and parents, friends or relatives who are or have been entrepreneurs (role model) (yes $=69$ per cent; no $=31$ per cent $)$.

The sample is then selected, limiting the respondents mostly to the 17-24 age group and to a tertiary level of education (current undergraduate students). These subjects should be able to understand the meaning of the ESE skills and reasons for start-ups as they are stated in the survey.

The common practice of using university students as proxies for entrepreneurs is often frowned upon; however Hemmasi and Hoelscher (2005) find that a student sample is very similar to actual entrepreneurs provided that its members have high entrepreneurial potential. 


\section{Table 1}

Factor categorisation for entrepreneurial empowerment (EE) items

\begin{tabular}{|l|c|}
\hline Factor items & Factor loading \\
\hline Opportunity recognition & \\
\hline Set and meet market share goals & 0.838 \\
\hline Set and meet sales goals & 0.794 \\
\hline Establish positioning in market & 0.850 \\
\hline Conduct market analysis & 0.757 \\
\hline Innovation & \\
\hline Develop new business ideas & 0.824 \\
\hline Develop new markets/products & 0.778 \\
\hline Find new markets and territories & 0.739 \\
\hline Develop new methods of production, etc & 0.536 \\
\hline Management & \\
\hline Reduce risk and deal with uncertainty & 0.786 \\
\hline Plan strategically & 0.780 \\
\hline Establish and achieve goals and objectives & 0.884 \\
\hline Define organisational roles, etc & 0.819 \\
\hline Risk taking & \\
\hline Take calculated risks & 0.805 \\
\hline Be comfortable with uncertainty and risk & 0.524 \\
\hline Take responsibility for ideas and decisions & 0.938 \\
\hline Work under pressure and conflict & 0.795 \\
\hline Financial control & 0.768 \\
\hline Perform financial analysis & 0.882 \\
\hline Control costs & \\
\hline Develop financial systems and internal controls & \\
\hline
\end{tabular}

\section{Table 2}

Factors with eigen values, variances explained and Cronbach's Alphas

\begin{tabular}{|l|c|c|c|}
\hline Factor & Eigen value & Percent of variance & Cronbach's Alpha \\
\hline Opportunity recognition & 2.967 & 74.171 & 0.882 \\
\hline Innovation & 2.554 & 63.861 & 0.810 \\
\hline Management & 3.003 & 75.084 & 0.889 \\
\hline Risk taking & 2.764 & 69.099 & 0.849 \\
\hline Financial control & 2.365 & 78.821 & 0.861 \\
\hline
\end{tabular}




\subsection{Statistical results}

Descriptive statistics are reported for the items relating to reasons for start-up (see Table 3), with the highest mean score for the item 'I see few other possibilities; the only chance to work is for myself', followed by 'I will continue family tradition'. Most mean scores represent the midpoint average, with no significant preference for being self-employed or working for someone. ANOVA (not shown) indicates F values of 0.358 and 0.197 , both of which are not statistically significant.

Table 4 represents the mean scores and deviations for the explanatory variable pertaining to parents, friends or relatives who are or have been entrepreneurs. This data was gathered from individual answers and from answers for reasons for start-up. Although the group statistics indicate relatively stable means and standard deviations across the factors, Levene's test for equality of variances renders F statistics that are not significant at the 0.05 or 0.01 levels. More importantly, however, an independent sample $t$-test for equality of means was conducted (not shown), and detected no significant differences.

For the explanatory variable relating to degree of preference for starting one's own business (see Table 5), testing for homogeneity of variances using Levene statistics indicates significance at the 0.05 and 0.01 levels for factors 1, 2, 3 and 4. ANOVA however indicates no significant differences in the between-group and within-group statistics. Similarly, for the degree of preference for being employed by someone (see Table 6), the Levene statistics indicate significance at the 0.05 and 0.01 levels but ANOVA indicates no significant differences in the between-group and within-group statistics.

Table 3

Reasons for start-ups: item statistics

\begin{tabular}{|l|c|c|}
\hline Items & Mean & $\begin{array}{c}\text { Std. } \\
\text { deviation }\end{array}$ \\
\hline Reason for start-up - I want to be my own boss & 2.48 & 1.656 \\
\hline Reason for start-up - I want freedom at work & 2.43 & 1.576 \\
\hline Reason for start-up - I would like to achieve and get approval & 2.52 & 1.623 \\
\hline Reason for start-up - I will continue family tradition & 2.83 & 1.458 \\
\hline Reason for start-up - I would like to develop a business idea & 2.54 & 1.488 \\
\hline Reason for start-up - I would like to have more influence in the community & 2.50 & 1.470 \\
\hline Reason for start-up - I see a promising opportunity to seize & 2.64 & 1.299 \\
\hline Reason for start-up - I would like to grow as a person & 2.39 & 1.696 \\
\hline Reason for start-up - I want to realise my dreams & 2.24 & 1.669 \\
\hline Reason for start-up - I want to have control of my life & 2.32 & 1.690 \\
\hline Reason for start-up - I want to provide security for my family & 2.30 & 1.655 \\
\hline Reason for start-up - I want to get life-time employment & 2.31 & 1.600 \\
\hline $\begin{array}{l}\text { Reason for start-up - I see few other possibilities; the only chance to work } \\
\text { is for myself }\end{array}$ & 2.85 & 1.245 \\
\hline
\end{tabular}




\section{Table 4}

Descriptive statistics: parents, friends or relatives as entrepreneurs

\begin{tabular}{|c|c|c|c|c|c|}
\hline Factors & $\begin{array}{l}\text { Do you have any parents, } \\
\text { friends or relatives who are or } \\
\text { have been entrepreneurs? }\end{array}$ & $\mathbf{N}$ & Mean & $\begin{array}{c}\text { Std } \\
\text { deviation }\end{array}$ & $\begin{array}{c}\text { Std error } \\
\text { mean }\end{array}$ \\
\hline \multirow{2}{*}{$\begin{array}{l}\text { Opportunity } \\
\text { recognition }\end{array}$} & Yes & 77 & 2.7987 & 0.98928 & 0.11274 \\
\hline & No & 35 & 2.6857 & 0.89184 & 0.15075 \\
\hline \multirow[t]{2}{*}{ Innovation } & Yes & 78 & 2.7885 & 0.84427 & 0.09559 \\
\hline & No & 35 & 2.7929 & 0.93243 & 0.15761 \\
\hline \multirow[t]{2}{*}{ Management } & Yes & 79 & 2.7215 & 1.02375 & 0.11518 \\
\hline & No & 35 & 2.7714 & 1.04384 & 0.17644 \\
\hline \multirow[t]{2}{*}{ Risk taking } & Yes & 79 & 2.7089 & 1.05417 & 0.11860 \\
\hline & No & 33 & 2.8485 & 1.16078 & 0.20207 \\
\hline \multirow{2}{*}{$\begin{array}{l}\text { Financial } \\
\text { control }\end{array}$} & Yes & 80 & 2.7583 & 1.05938 & 0.11844 \\
\hline & No & 36 & 2.8056 & 0.95743 & 0.15957 \\
\hline \multirow{2}{*}{$\begin{array}{l}\text { Reason for } \\
\text { start up }\end{array}$} & Yes & 77 & 2.5734 & 1.31485 & 0.14984 \\
\hline & No & 34 & 2.2964 & 1.29897 & 0.22277 \\
\hline
\end{tabular}

Table 5

Descriptive statistics: preference for starting own business

\begin{tabular}{|l|l|c|c|c|c|}
\hline Factors & & N & Mean & $\begin{array}{c}\text { Std } \\
\text { deviation }\end{array}$ & Std error \\
\hline $\begin{array}{l}\text { Opportunity } \\
\text { recognition }\end{array}$ & Very high & 39 & 2.679 & 1.263 & 0.202 \\
\cline { 2 - 6 } & High & 43 & 2.825 & 0.833 & 0.127 \\
\cline { 2 - 6 } & Moderate - very low & 29 & 2.732 & 0.574 & 0.106 \\
\cline { 2 - 6 } & Total & 111 & 2.750 & 0.951 & 0.090 \\
\hline \multirow{4}{*}{ Innovation } & Very high & 38 & 2.67 & 1.113 & 0.180 \\
\cline { 2 - 6 } & High & 44 & 2.858 & 0.743 & 0.112 \\
\cline { 2 - 6 } & Moderate - very low & 30 & 2.825 & 0.689 & 0.125 \\
\cline { 2 - 6 } & Total & 112 & 2.785 & 0.871 & 0.0823 \\
\hline \multirow{3}{*}{ Management } & Very high & 39 & 2.698 & 1.298 & 0.207 \\
\cline { 2 - 6 } & High & 44 & 2.704 & 1.020 & 0.153 \\
\cline { 2 - 6 } & Moderate - very low & 113 & 2.736 & 1.030 & 0.096 \\
\cline { 2 - 6 } & Total & & & & 0.105 \\
\hline
\end{tabular}




\begin{tabular}{|l|l|c|c|c|c|}
\hline \multirow{4}{*}{ Risk taking } & Very high & 40 & 2.756 & 1.318 & 0.208 \\
\cline { 2 - 6 } & High & 43 & 2.773 & 1.086 & 0.1657 \\
\cline { 2 - 6 } & Moderate - very low & 28 & 2.714 & 0.686 & 0.129 \\
\cline { 2 - 6 } & Total & 111 & 2.752 & 1.087 & 0.103 \\
\hline \multirow{4}{*}{$\begin{array}{l}\text { Financial } \\
\text { control }\end{array}$} & Very high & 40 & 2.733 & 1.208 & 0.191 \\
\cline { 2 - 6 } & High & 45 & 2.792 & 1.033 & 0.1539 \\
\cline { 2 - 6 } & Moderate - very low & 30 & 2.755 & 0.726 & 0.132 \\
\cline { 2 - 6 } & Total & 115 & 2.762 & 1.022 & 0.0953 \\
\hline \multirow{4}{*}{$\begin{array}{l}\text { Reason for } \\
\text { start up }\end{array}$} & Very high & 38 & 2.542 & 1.455 & 0.236 \\
\cline { 2 - 6 } & High & 43 & 2.391 & 1.336 & 0.2029 \\
\cline { 2 - 6 } & Moderate - very low & 29 & 2.567 & 1.124 & 0.208 \\
\cline { 2 - 6 } & Total & 110 & 2.490 & 1.316 & 0.1255 \\
\hline
\end{tabular}

Table 6

Descriptive statistics: preference for being employed by someone

\begin{tabular}{|c|c|c|c|c|c|}
\hline & & $\mathbf{N}$ & Mean & $\begin{array}{c}\text { Std } \\
\text { deviation }\end{array}$ & Std error \\
\hline \multirow{4}{*}{$\begin{array}{l}\text { Opportunity } \\
\text { eecognition }\end{array}$} & Very high / high & 43 & 2.784 & 0.967 & 0.147 \\
\hline & Moderate & 42 & 2.767 & 0.843 & 0.130 \\
\hline & Low / very low & 27 & 2.722 & 1.129 & 0.217 \\
\hline & Total & 112 & 2.763 & 0.957 & 0.090 \\
\hline \multirow[t]{4}{*}{ Innovation } & Very high / high & 43 & 2.837 & 0.881 & 0.134 \\
\hline & Moderate & 44 & 2.789 & 0.777 & 0.117 \\
\hline & Low / very low & 26 & 2.711 & 1.011 & 0.198 \\
\hline & Total & 113 & 2.789 & 0.868 & 0.0816 \\
\hline \multirow[t]{4}{*}{ Management } & Very high / high & 44 & 2.823 & 1.085 & 0.163 \\
\hline & Moderate & 44 & 2.676 & 0.944 & 0.142 \\
\hline & Low / very low & 26 & 2.692 & 1.082 & 0.212 \\
\hline & Total & 114 & 2.736 & 1.025 & 0.096 \\
\hline \multirow[t]{4}{*}{ Risk taking } & Very high / high & 42 & 2.952 & 0.974 & 0.150 \\
\hline & Moderate & 43 & 2.581 & 0.986 & 0.150 \\
\hline & Low / very low & 27 & 2.703 & 1.351 & 0.260 \\
\hline & Total & 112 & 2.750 & 1.083 & 0.102 \\
\hline
\end{tabular}




\begin{tabular}{|l|l|c|c|c|c|}
\hline \multirow{3}{*}{$\begin{array}{l}\text { Financial } \\
\text { control }\end{array}$} & Very high / high & 45 & 2.718 & 0.855 & 0.127 \\
\cline { 2 - 6 } & Moderate & 44 & 2.856 & 1.062 & 0.160 \\
\cline { 2 - 6 } & Low / very low & 27 & 2.728 & 1.233 & 0.237 \\
\cline { 2 - 6 } & Total & 116 & 2.773 & 1.024 & 0.095 \\
\hline \multirow{2}{*}{$\begin{array}{l}\text { Reason for } \\
\text { start up }\end{array}$} & Very high / high & 43 & 2.538 & 1.299 & 0.198 \\
\cline { 2 - 6 } & Moderate & 43 & 2.361 & 1.195 & 0.182 \\
\cline { 2 - 6 } & Low / very low & 25 & 2.621 & 1.537 & 0.307 \\
\cline { 2 - 6 } & Total & 111 & 2.488 & 1.310 & 0.124 \\
\hline
\end{tabular}

\subsection{Correlation and regression analysis}

To evaluate the hypothesised relationships between the variables, correlational analysis and multiple regression analysis were performed. It has been suggested that the correlation significance should be checked before making comparisons (Cooper \& Emory, 1995: 485). For the correlation matrix (see Table 7), the Pearson correlation coefficients are reported with the values in the second line of each row indicating the $\mathrm{p}$ values. According to Cohen and Holliday (1998: 101), a multiple correlation coefficient of 0.7 or above is considered a high relationship. Anastasia and Urbani (1997) maintain it should be high enough to be statistically significant at the 0.05 and 0.01 levels.
For this study's results, the levels of correlation are generally high and all correlations are statistically significant, which offers preliminary support for the hypotheses. As hypothesised, all the variables indicate significant positive correlations with reasons for start-up, (the explanatory variables 'parents' and 'preference for self-employment' were not entered into the correlation matrix as no significant differences were detected in the preceding analysis). The highest correlation coefficient between the predicted relationship of the EE sub-dimension management and reason for start-up is 0.740 .

As anticipated in the instrument design, the results reveal that variables are vulnerable to multicollearanity (when some or all the variables are highly correlated, i.e., correlation is at 0.80 or more) (Cooper \& Emory, 1995). This is addressed in the next section, the interpretation of the regression analysis.

\section{Table 7}

Correlation analysis with Pearson's correlation coefficients

\begin{tabular}{|l|c|c|c|c|c|c|c|}
\hline \multirow{2}{*}{ Factors } & $\begin{array}{c}\text { Opportu- } \\
\text { nity } \\
\text { recogni- } \\
\text { tion }\end{array}$ & $\begin{array}{c}\text { Inno- } \\
\text { vation }\end{array}$ & $\begin{array}{c}\text { Manage- } \\
\text { ment }\end{array}$ & $\begin{array}{c}\text { Risk } \\
\text { taking }\end{array}$ & $\begin{array}{c}\text { Financial } \\
\text { control }\end{array}$ & $\begin{array}{c}\text { Reason } \\
\text { for start } \\
\text { up }\end{array}$ \\
\hline \multirow{2}{*}{$\begin{array}{c}\text { Opportunity } \\
\text { recognition }\end{array}$} & $\begin{array}{c}\text { Pearson } \\
\text { correlation }\end{array}$ & 1 & $0.794^{* *}$ & $0.840^{* *}$ & $0.753^{* *}$ & $0.733^{* *}$ & $0.693^{* *}$ \\
\cline { 2 - 8 } & $\begin{array}{c}\text { Sig. } \\
(2 \text {-tailed) }\end{array}$ & & 0.000 & 0.000 & 0.000 & 0.000 & 0.000 \\
\cline { 2 - 8 } & $\mathrm{N}$ & 112 & 109 & 110 & 108 & 112 & 106 \\
\hline
\end{tabular}




\begin{tabular}{|c|c|c|c|c|c|c|c|}
\hline \multirow[t]{3}{*}{ Innovation } & $\begin{array}{c}\text { Pearson } \\
\text { correlation }\end{array}$ & $0.794^{* *}$ & 1 & $0.720^{* *}$ & $0.686^{* *}$ & $0.535^{* *}$ & $0.583^{* *}$ \\
\hline & $\begin{array}{c}\text { Sig. } \\
\text { (2-tailed) }\end{array}$ & 0.000 & & 0.000 & 0.000 & 0.000 & 0.000 \\
\hline & $\mathrm{N}$ & 109 & 113 & 113 & 109 & 113 & 107 \\
\hline \multirow[t]{3}{*}{ Management } & $\begin{array}{c}\text { Pearson } \\
\text { correlation }\end{array}$ & $0.840^{* *}$ & $0.720^{* *}$ & 1 & $0.874^{* *}$ & $0.645^{* *}$ & $0.740^{* *}$ \\
\hline & $\begin{array}{c}\text { Sig. } \\
\text { (2-tailed) }\end{array}$ & 0.000 & 0.000 & & 0.000 & 0.000 & 0.000 \\
\hline & $\mathrm{N}$ & 110 & 113 & 114 & 110 & 114 & 108 \\
\hline \multirow[t]{3}{*}{ Risk taking } & $\begin{array}{c}\text { Pearson } \\
\text { correlation }\end{array}$ & $0.753^{* *}$ & $0.686^{* *}$ & $0.874^{* *}$ & 1 & $0.570^{* *}$ & $0.771^{* *}$ \\
\hline & $\begin{array}{c}\text { Sig. } \\
\text { (2-tailed) }\end{array}$ & 0.000 & 0.000 & 0.000 & & 0.000 & 0.000 \\
\hline & $\mathrm{N}$ & 108 & 109 & 110 & 112 & 112 & 107 \\
\hline \multirow[t]{3}{*}{$\begin{array}{l}\text { Financial } \\
\text { control }\end{array}$} & $\begin{array}{c}\text { Pearson } \\
\text { correlation }\end{array}$ & $0.733^{* *}$ & $0.535^{* *}$ & $0.645^{* *}$ & $0.570^{* *}$ & 1 & $0.504^{* *}$ \\
\hline & $\begin{array}{c}\text { Sig. } \\
\text { (2-tailed) }\end{array}$ & 0.000 & 0.000 & 0.000 & 0.000 & & 0.000 \\
\hline & $\mathrm{N}$ & 112 & 113 & 114 & 112 & 116 & 110 \\
\hline \multirow[t]{3}{*}{$\begin{array}{l}\text { Reason for } \\
\text { start up }\end{array}$} & $\begin{array}{c}\text { Pearson } \\
\text { correlation }\end{array}$ & $0.693^{* *}$ & $0.583^{* *}$ & $0.740^{* *}$ & $0.771^{* *}$ & $0.504^{* *}$ & 1 \\
\hline & $\begin{array}{c}\text { Sig. } \\
\text { (2-tailed) }\end{array}$ & 0.000 & 0.000 & 0.000 & 0.000 & 0.000 & \\
\hline & $\mathrm{N}$ & 106 & 107 & 108 & 107 & 110 & 111 \\
\hline
\end{tabular}

** Correlation is significant at the 0.01 level (2-tailed)

The use of multiple regressions allows for the partitioning of variance with correlated predictors, thereby reducing the likelihood of making a Type 1 error. The coefficient of multiple determinations was used to compute what proportion of the variance of the dependent variables is due to the combined effects of the predictors (Cohen \& Holliday, 1998: 98). The sign of the regression coefficients indicates the nature of the relationship between the variables under study.

Although no rule exists as to what fraction of variance needs to be explained if the relationship is to be considered strong, many researches say a squared multiple correlation of 0.3 or greater implies at least a moderately strong relationship (Sudman \& Blair, 1998: 517).
The regression procedure uses stepwise regression; first the variables that contribute the most to explaining the dependent variable are entered, and the rest of the variables included in order of their incremental contribution after the first variable, provided they are statistically significant. Using this procedure, 'risk taking' and 'opportunity recognition' (see Table 8) produce models 1 and 2 with an adjusted $\mathrm{R}$ square of 0.579 and 0.607 respectively. Interpreting model 1 we can say that 'risk taking' as a predictor explains 58 per cent of the variance in the reasons for start-up. From model 2 we can say that including 'opportunity recognition' only improves the explanation slightly (61 per cent). 
In Table 9 the ANOVA calculates an F value which has an overall role for both the models and for each of the independent variables and measures. The results in this case represent a set of regression coefficients that are statistically significant from zero.

In Table 10, collinearity diagnostics reveal relatively high variance proportions (e.g., model 2 , dimension $3=0.75$ and 0.95 ). Such diagnostics should be read in conjunction with the collinearity statistics from Table 9 , where the variable inflation factor (VIF) values of 1.000 for model 1 and 2.225 for model 2 suggest that model 1 is acceptable but that model 2, with its high value, suffers from multicollinearity. When the values are 10.0 or more the regression coefficients can fluctuate widely from sample to sample, making it risky to interpret the coefficients as indicators of predictors (Cooper \& Emory, 1995).

\section{Table 8}

Regression: model summaries

\begin{tabular}{|c|c|c|c|c|}
\hline Model & R & R square & Adjusted R square & Std error of the estimate \\
\hline 1 & $0.763(\mathrm{a})$ & 0.583 & 0.579 & 0.848 \\
\hline 2 & $0.784(\mathrm{~b})$ & 0.615 & 0.607 & 0.819 \\
\hline
\end{tabular}

a Predictors: (Constant), risk taking

b Predictors: (Constant), risk taking, opportunity recognition

\section{Table 9}

Regression for Model 1 and 2: ANOVA tests

\begin{tabular}{|c|l|c|r|r|r|c|}
\hline Model & & Sum of squares & df & Mean square & F & Sig. \\
\hline \multirow{2}{*}{$\mathbf{1}$} & Regression & 98.524 & 1 & 98.524 & 136.931 & $0.000(\mathrm{a})$ \\
\cline { 2 - 7 } & Residual & 70.513 & 98 & 0.720 & & \\
\cline { 2 - 7 } & Total & 169.037 & 99 & & & $0.000(\mathrm{~b})$ \\
\hline \multirow{2}{*}{$\mathbf{2}$} & Regression & 103.885 & 2 & 51.943 & 77.334 & \\
\cline { 2 - 7 } & Residual & 65.152 & 97 & 0.672 & & \\
\cline { 2 - 7 } & Total & 169.037 & 99 & & & \\
\hline
\end{tabular}

a Predictors: (Constant), risk taking

b Predictors: (Constant), risk taking, opportunity recognition

c Dependent Variable: reason for start up

\section{Table 10}

Regression for Model 1 and 2: coefficients and collinearity diagnostics

\begin{tabular}{|c|c|c|c|c|c|c|c|c|}
\hline \multirow[t]{2}{*}{ Model } & & \multicolumn{2}{|c|}{$\begin{array}{l}\text { Unstandardised } \\
\text { coefficients }\end{array}$} & \multirow{2}{*}{$\begin{array}{c}\begin{array}{c}\text { Standardised } \\
\text { coefficients }\end{array} \\
\text { Beta }\end{array}$} & \multirow[t]{2}{*}{$t$} & \multirow[t]{2}{*}{ Sig. } & \multicolumn{2}{|c|}{$\begin{array}{c}\text { Collinearity } \\
\text { statistics }\end{array}$} \\
\hline & & B & $\begin{array}{l}\text { Std } \\
\text { error }\end{array}$ & & & & $\begin{array}{l}\text { Tole- } \\
\text { rance }\end{array}$ & VIF \\
\hline \multirow[t]{2}{*}{1} & (Constant) & -0.095 & 0.236 & & -0.403 & 0.688 & & \\
\hline & Risk taking & 0.947 & 0.081 & 0.763 & 11.702 & 0.000 & 1.000 & 1.000 \\
\hline \multirow[t]{3}{*}{2} & (Constant) & -0.457 & 0.261 & & -1.746 & 0.084 & & \\
\hline & Risk taking & 0.703 & 0.117 & 0.566 & 6.022 & 0.000 & 0.449 & 2.225 \\
\hline & $\begin{array}{l}\text { Opportunity } \\
\text { recognition }\end{array}$ & 0.374 & 0.132 & 0.266 & 2.825 & 0.006 & 0.449 & 2.225 \\
\hline
\end{tabular}

a Dependent variable: reason for start-up 
3

\section{Conclusion}

\subsection{Conclusion}

The results from this study contribute to the body of research on predicting an individual's perception of empowerment in an entrepreneurial context. Moreover, the instruments used, which have not been previously tested in non-Western countries, are validated here in a South African context. The factor structure of entrepreneurial empowerment used in this study in the form of entrepreneurial self-efficacy sub-dimensions is thus confirmed as a robust scale able to deliver construct validity and reliability. Essentially this instrument captures the notion of how an empowered individual feels more efficacious in starting a business. Such validation is particularly relevant in the African context where psychological variables such as personal empowerment, innovativeness and autonomy explain differences in entrepreneurs' reaction to the environment (Luiz, 2006).

The correlation and regression results provide almost unequivocal support for both hypotheses, namely the association between entrepreneurial empowerment and start-up, and reasons for start-up. A substantial amount of variance in start-up is explained by two of the empowerment sub-factors. The stepwise regression procedure reveals that the high correlation and regression results can explain the effects of empowerment on reasons for business start-up to a large extent. In particular the level of perceived efficacy at taking calculated risks is important towards explaining empowerment.

From these results, prospective entrepreneurs with a high capacity for taking risks will arguably be predisposed to start their own ventures for a variety of reasons. This finding is congruent with previous research on how empowered individuals see more opportunities in a risky venture and take more risks (Krueger \& Dickson, 1994).

Surprisingly, in contrast to both common sense and previous findings, having a parent, friend or relative who is or has been an entrepreneur does not increase an individual's perception of empowerment or significantly affect reasons for start-up. The extant literature suggests that the social context (family/education) can both limit and enable participant agency in innovation and enterprise activities, but is generally accepted as being positively linked to greater self-employment (O'Conner \& Ramos, 2006). Based on such established findings, this paper's preliminary finding needs additional analysis.

The focal point of this research is preference for starting one's own business based on perceptions of empowerment. The results of this study show no significant difference in this preference according to reason for startup. Where previous research finds that selfemployed individuals tend to report higher levels of ESE (Krueger et al., 2000; Bradley \& Roberts, 2004), the failure of this present study to find any significant effects of these explanatory variables suggests that entry into self-employment may be a complex decision which is also mediated by environmental conditions.

\subsection{Implications}

Although empowerment deal-making has increased exponentially in South Africa, there is still a scarcity of blacks wanting to start and build their own businesses. The entry of blacks into the economy has been gathering pace in past years but has been limited by the restriction of black entrepreneurs involved in the day-to-day running of businesses (Lediga, 2006). It seems that, in South Africa, empowerment has happened at the expense of entrepreneurship, contradicting both commonsense and research findings, as discussed in section 1 of this paper.

Policy makers could benefit from understanding that government initiatives will affect business formation only if these policies are perceived in a way that influences intentions and self-efficacy (Krueger et al., 2000). Government initiatives which focus on a 'do it alone' approach tend to produce an entitlement mentality. The psychological component of empowerment is pivotal, and considering the role of the individual in venture creation, it is imperative that policy makers recognise how an individual's intentions make things happen through his/her own actions. 
The entire entrepreneurial process unfolds because individual entrepreneurs act and are motivated to pursue opportunities. Feeling efficacious must not only be considered an integral aspect of empowerment but also be supplemented with education and training, since empowerment without the requisite skills, knowledge and attitudes nullifies the formula for empowered entrepreneurship.

Researchers and academics must continue to develop rigorous theoretical frameworks to understand empowerment and the reasons for self-employment in the context of entrepreneurship.

\subsection{Limitations and future research}

The selected measures, which juxtapose selfemployment against employment by another, can be argued (e.g. Kolvereid \& Isaksen, 2006) to be an over-simplification which does not allow for other possibilities, e.g. people can choose to be unemployed or unemployable, or some mixture of full-time salaried work and part-time self-employment. Given that people can combine entrepreneurship with employment, defining self-employment as a continuous construct is likely to be a more valid and precise indicator of selfemployment.

Cross-sectional studies do not allow for true testing of causal relations. The relationships between empowerment, intentions and behaviour over time need to be examined. Such research is particularly important since some researchers e.g. Katz (1990) question the intention-behaviour link.

This study is also prone to social desirability bias; since 'entrepreneurship' is a charismatically charged term, and carries a lot of social weight, respondents may have overestimated their abilities.

Finally, entrepreneurial empowerment can only be understood as a constellation of personality and environmental features of which self-efficacy is only a part. Studies could also be extended to include contextual factors such as legislation and educational systems to help explain venture formation as a more holistic process.

\section{References}

1 AJZEN, I. (1991) "Theory of planned behaviour", Organizational Behaviour and Human Decision Processes, 50: 179-211.

2 ANASTASIA, A. \& URBANI, S. (1997) Psychological Testing ( $7^{\text {th }}$ ed.) Prentice Hall: Eaglewood Cliffs NJ.

3 ANNA, A.L.; CHANDLER, G.N.; JANSEN, E. \& MERO, N.P. (2000) "Women business owners in traditional and non-traditional industries", Journal of Business Venturing, 15(3): 279-303.

4 APPELBAUM, S.H. \& HONEGGAR, K. (1998)

"Empowerment: A contrasting overview of organisations in general and nursing in particular - an examination of organisational factors, managerial behaviours, job design, and structural power", Empowerment in Organisations, 6(2): 29-50.

5 BANDURA, A. (1986) Social Foundations of Thought and Action: A Social Cognitive Theory. Prentice-Hall: Englewood Cliffs, NJ.

6 BANDURA, A. (1997) Self-efficacy: The Exercise of Control. W.H. Freeman: New York.

7 BANDURA, A. (2001) "Social cognitive theory: An agentic perspective", Annual Review of Psychology, 42: 1-36.

8 BRADLEY, D.E. \& ROBERTS, J.A. (2004) "Selfemployment and job satisfaction: Investigating the role of self-efficacy, depression, and seniority", Journal of Small Business Management, 42(1): 37-58.

9 BUITENDACH, J.H. \& HLALELE, R.R.T. (2005) "Psychological empowerment and job satisfaction of engineers in a petrochemical industry", South Africa Journal of Economic and Management Sciences, 8(2): 154-170.

10 CHANDLER, G.N. \& JANSEN, E. (1992) “The founders self assessed competence and venture performance", Journal of Business Venturing, 7: 223-236.

11 CHEN, C.C.; GREENE, P.G. \& CRICK, A. (1998) "Does entrepreneurial self-efficacy distinguish entrepreneurs from managers?" Journal of Business Venturing, 13: 295-316.

12 CLOETE, V.J.; CROUS, F. \& SCHEPERS, J.M. (2002) "The construction and evaluation a scale on employee empowerment", South African Journal of Industrial Psychology, 28(2): 31-36.

13 COHEN, L. \& HOLLIDAY, M. (1998) Practical Statistics for Students. Paul Chapman Publishing: London.

14 CONGER, J.A. \& KANUNGO, R, N. (1988) “The empowerment process: Integrating theory and practice", Academy of Management Review, 13(3): 34-56. 
15 COOPER, R.D. \& EMORY, C.W. (1995) Business Research Methods (5 ${ }^{\text {th }}$ ed.) Irwin: Chicago.

16 DOUGLAS, E.J. \& SHEPHERD, D.A. (2002) "Self-employment as a career choicer: attitudes, entrepreneurial intentions and utility maximization", Entrepreneurship Theory and Practice, 40: 81-90.

17 DRIVER, A.; WOOD, E.; SEGAL, N. \& HERRINGTON, M. (2001) Global Entrepreneurship Monitor South African Executive Report, University of Cape Town: Cape Town.

18 DRNOVSEK, M. \& GLAS, M. (2002) "The entrepreneurial self-efficacy of nascent entrepreneurs: The case of two economies in transition", Journal of Enterprising Culture, 10 (2): 107-131.

19 FORD, C.M. (1996) "A theory of individual creative action in multiple social domains", Academy of Management Review, 21(4): 102-120.

20 GATEWOOD, E.J.; SHAVER, K.G.; POWERS, J.B. \& GARTNER, W.B. (2002) "Entrepreneurial expectancy, task effort, and performance", Entrepreneurship Theory and Practice, 52: 187-206.

21 GIST, M.E. \& MITCHELL, T.R. (1992) "Selfefficacy: A theoretical analysis of its determinants \& malleability", Academy Of Management Review, 17(2): 183-212.

22 HEMMASI, M. \& HOELSCHER, M. (2005) "Entrepreneurship research, using students as proxies for actual entrepreneurs", Proceedings of the 50th Annual Conference of the International Council for Small Business, Washington D.C. June 15-20.

23 KANTOR, P. (2002) "Gender, microenterprise success and cultural context: the case of South East Asia", Entrepreneurship Theory and Practice, 26(4): 131-143.

24 KATZ, J.A. (1990) "Longitudinal analysis of selfemployment follow through", Entrepreneurship and Regional Development, 2(1): 15-25.

25 KOLVEREID, L. \& ISAKSEN, E. (2006) “New business start-up and subsequent entry into selfemployment", Journal of Business Venturing, 21: 866-885.

26 KOLVEREID, L. (1996) "Prediction of employment status choice intentions", Entrepreneurship Theory and Practice, 21(1): 47-57.

27 KRUEGER, N.F. \& BRAZEAL, D.V. (1994) "Entrepreneurial potential and potential entrepreneurs", Entrepreneurship Theory and Practice, 18: 91-105.

28 KRUEGER, N.F. \& DICKSON, P.R. (1994) "How believing in ourselves increases risk taking: self-efficacy and perceptions of opportunity and threats", Decision Sciences, 25: 103-123.
29 KRUEGER, N.F.; REILLY, M.D. \& CARSRUD, A.L. (2000) "Competing models of entrepreneurial intentions", Journal of Business Venturing, 15: 411-432.

30 LEDIGA, C. (2006) "Empowerment needs entrepreneurship too", Business Times Supplement, Sunday Times, November 19: 10.

31 LUIZ, J. (2006) Managing Business in Africa: Practical Management Theory for an Emerging Market. Oxford University Press: Cape Town.

32 MARKMAN, G.D.; BALKIN, D.B. \& BARON, R.A. (2002) "Inventors and new venture formation: the effects of general self-efficacy and regretful thinking", Entrepreneurship Theory and Practice, 49: 149-165.

33 MENON, S.T. (2001) "Employee empowerment: An integrative psychology approach", Applied Psychology: An International Review, 50(1): 153-180.

34 MOUTON, J. (2002) Understanding Social Research. Van Schaik: Pretoria.

35 NAFFZIGER, D.W.; HORNSBY, S.J. \& KURATKO, D.F. (1994) "A proposed research model of entrepreneurial motivation", Entrepreneurship Theory and Practice, 31: 29-42.

36 NOBLE A.F.; JUNG, D. \& EHRLICH, S.B. (1999) "Entrepreneurial self-efficacy: The development of a measure and its relationship to entrepreneurial action", Frontiers of Entrepreneurship Research, Babson College.

37 NUNNALLY, J.C. (1978) Psychometric Theory (2nd ed.) McGraw-Hill: New York.

38 O'CONNOR, A. \& RAMOS, J.M. (2006) "Empowering entrepreneurship through foresight and innovation: developing a theoretical framework for empowerment in enterprise programs", Journal of Developmental Entrepreneurship, 11(3): 207-231.

39 SCHERER, F.R.; ADAMS, J.S.; CARLEY, S.S. \& WIEBE, F.A. (1989) "Role model performance effects on development of entrepreneurial career preference", Entrepreneurship Theory and Practice, 24: 53-71.

40 SHANE, S., KOLVEREID, L. \& WESTHEAD, P. (1991) "An exploratory examination of the reasons leading to new firm formation across country and gender", Journal of Business Venturing, 6: 431-446.

41 SHANE, S., LOCKE, E.A. \& COLLINS, C.J. (2003) "Entrepreneurial motivation", Human Resource Management Review, 13: 257-279.

42 SA BUSINESS GUIDEBOOK. (2005/6) No. 115-118.

43 SPREITZER, G.M. (1995) "Psychological empowerment in the workplace: dimensions, 
measurements and validation", Academy of Management Journal, 38: 1142-1465.

44 STEVENS, C.K. \& GIST, M.E. (1997) "Effects of self-efficacy and goal oriented training on negotiation skill maintenance: What are the mechanisms?" Personnel Psychology, 50(4): 955-979.

45 SUDMAN, S. \& BLAIR, E. (1998) Marketing Research: A Problem Solving Approach, McGrawHill: Boston.
46 THOMAS, K.W. \& VELTHOUSE, B.A. (1990)

"Cognitive elements of empowerment: an interpretive model intrinsic task motivation", Academy of Management Review, 15: 666-681.

47 VAN JAARSVELD, M. (2005) "Black economic empowerment and skills development: A success in many ways", South African Mercantile Law Journal, 17: 261-275.

48 WHETTEN, D.A. \& CAMERON, K.S. (2005) Developing Management Skills, (6 $6^{\text {th }}$ ed.) Pearson: NJ. 